\title{
Perception about pap smear screening test among females attending a tertiary care center
}

\section{A. Shantha, Priya Somu*}

Department of Obstetrics and Gynecology, Sri Muthukumaran Medical College Hospital and Research Institute, Chennai, Tamil Nadu, India

Received: 12 February 2020

Accepted: 03 March 2020

*Correspondence:

Dr. Priya Somu,

E-mail: drpriyar@ymail.com

Copyright: (C) the author(s), publisher and licensee Medip Academy. This is an open-access article distributed under the terms of the Creative Commons Attribution Non-Commercial License, which permits unrestricted non-commercial use, distribution, and reproduction in any medium, provided the original work is properly cited.

\section{ABSTRACT}

Background: Knowledge regarding the screening test (Pap smear) among women has been proven to be a significant predictor of first-time screening and in turn helps in early diagnosis and treatment of the disease. Hence this study was conducted to assess the knowledge and practice of pap smear screening test for cervical cancer among the women attending the outpatient department of obstetrics and gynecology.

Methods: The cross-sectional study was conducted by the department of obstetrics and gynecology, at Sri Muthukumaran Medical College Hospital and Research Institute, among the women attending the outpatient department, during the month of August 2019. A total of 180 participants were included in the study. Data was entered in Microsoft excel and data analysis was done using statistical package for social sciences (SPSS) version 17.

Results: Knowledge about carcinoma cervix and pap smear were present among $86.7 \%$ and $74.4 \%$ of participants, respectively. About the practice of pap smear, only $24.4 \%$ of the study participant have undergone the screening test and only two participants had taken the HPV vaccine.

Conclusions: Most of the women had poor attitude and practice related to screening and vaccination for cervical cancer. But their attitude is favorable for screening. Hence promotion of free regular health check-up and vaccination for cervical cancer among general population might increase the awareness and decrease the disease burden.

Keywords: Carcinoma cervix, Female, Pap smear, Perception

\section{INTRODUCTION}

Cervical cancer is a common cancer among both rural and urban women of India. ${ }^{1}$ It has well known risk factors and an identifiable precancerous stage which is called as Cervical dysplasia. The precancerous and the early stages of invasive cervical cancer can be detected through visual inspection with Lugol's iodine or visual inspection with acetic acid or cytological smear examination. ${ }^{2,3}$ It has been documented that detection at the precancerous or early stage of invasive cancer along with early treatment reduces mortality and morbidity of cervical cancer. ${ }^{4}$ Knowledge regarding Pap smear test among women has been proven to be a significant predictor of first time screening. ${ }^{5}$
Most cases of cervical cancer in India are diagnosed at later and more serious stages which will reduce the survival rate of women with cervical cancer. The prime reason for late stage diagnosis of disease is a lack of awareness about screening and preventive methods of cervical cancer. Screening for cervical cancer is essential as the women often do not experience symptoms until the disease has advanced. ${ }^{6}$ The most common symptoms present in cervical cancer are bleeding between periods, persistent back pain, pelvic pain, bleeding after intercourse, urinary urgency, unexplained weight loss, and severe swelling in one or both legs. Infection with human papillomavirus (HPV), particularly HPV 16 and 18 strains cause $75 \%$ of cervical cancers globally. ${ }^{7}$ Other risk factors include having multiple sexual partners, early 
age of sexual intercourse, tobacco consumption, prolonged use of oral contraceptive pills, increased parity, and early age of giving birth. ${ }^{8}$

Objectives of this study was to assess the knowledge and practice of pap smear screening test for cervical cancer among the women attending the outpatient department of obstetrics and gynecology.

\section{METHODS}

The cross-sectional study was conducted by the department of obstetrics and gynecology, at Sri Muthukumaran Medical College Hospital and Research Institute, among the women attending the outpatient department, during the month of August 2019. Based on the literature, considering the knowledge about the screening test as $69 \%$ with confidence of $95 \%$ and relative precision of $10 \%$, the sample size was calculated as hundred and seventy-three and it was rounded to hundred and eighty. ${ }^{9}$ Hence, a total of 180 participants were included in the study. All women between 15- 65 years of age who were attending the outpatient department of obstetrics and gynecology were included in the study. Participants with known history of cervical cancer and gravid mothers were excluded from the study.

The principal investigator explained the purpose of the study to each participant and a written consent was obtained from the participants prior to the commencement of the study. The participants were also informed that their participation was voluntary and that they could withdraw from the interview at any time without consequences. Every effort was made, to be sure that all information collected from the participants, remain confidential. The study was conducted using a questionnaire, covering particulars related to knowledge and practice components of the screening test pap smear.

\section{Statistical analysis}

Data was entered in Microsoft excel and data analysis was done using Statistical Package for Social Sciences (SPSS) version 17.

\section{RESULTS}

In the present study the mean age of the study participants was found to be $44.53 \pm 12.48$ years. Majority of the study participants $(28.9 \%)$ were in the age group of $41-50$ years of age followed by $24.4 \%, 21.1 \%, 18.9 \%$ and $6.7 \%$ of participants in the age group of $31-40$ years, less than 30 years, 51-60 years and more than 60 years of age, respectively. Among the study participants only $40.6 \%$ were literate and $22.8 \%$ were employed. Also, majority of the study participants $(85 \%)$ were married. Based on modified Prasad's socioeconomic status scale $35 \%$ of the participants were belongs to class 2. Also $60.6 \%$ of participants were from rural area and $39.4 \%$ were from urban area (Table 1).
Table 1: Demographic characteristics of the study participants.

\begin{tabular}{|lll|}
\hline Variables & Frequency & Percentage \\
\hline Age group & & \\
\hline$<30$ years & 38 & $21.1 \%$ \\
\hline $31-40$ years & 44 & $24.4 \%$ \\
\hline $41-50$ years & 52 & $28.9 \%$ \\
\hline $51-60$ years & 34 & $18.9 \%$ \\
\hline $61-65$ years & 12 & $6.7 \%$ \\
\hline Literacy & & \\
\hline Illiterate & 107 & $59.4 \%$ \\
\hline Literate & 73 & $40.6 \%$ \\
\hline Occupation & & \\
\hline Housewife & 139 & $77.2 \%$ \\
\hline Employed & 41 & $22.8 \%$ \\
\hline Marital status & & \\
\hline Married & 153 & $85 \%$ \\
\hline Unmarried & 27 & $15 \%$ \\
\hline Socio economic status & \\
\hline Class 1 & 38 & $21.1 \%$ \\
\hline Class 2 & 63 & $35 \%$ \\
\hline Class 3 & 43 & $23.9 \%$ \\
\hline Class 4 & 25 & $13.9 \%$ \\
\hline Class 5 & 11 & $6.1 \%$ \\
\hline Area of residence & & $39.4 \%$ \\
\hline Urban area & 71 & \\
\hline Rural area & 109 & \\
\hline & & \\
\hline
\end{tabular}

Table 2: Knowledge about carcinoma cervix and pap smear.

\begin{tabular}{|lll|}
\hline Heard about & Frequency & Percentage \\
\hline Carcinoma cervix & 156 & $86.7 \%$ \\
\hline Pap smear screening & 134 & $74.4 \%$ \\
\hline Human papilloma virus & 43 & $23.9 \%$ \\
\hline HPV vaccine & 21 & $11.7 \%$ \\
\hline
\end{tabular}

About the knowledge of carcinoma cervix and pap smear, $86.7 \%$ and $74.4 \%$ of the study participants were found to be heard about carcinoma cervix and pap smear screening test, respectively. Whereas only $23.9 \%$ of the participants were aware about the human papilloma virus and only $11.7 \%$ of the study participant were heard about the HPV vaccine (Table 2).

Table 3: Practice of pap smear and taking HPV vaccine.

\begin{tabular}{|ll|l|}
\hline Practice components & Frequency & Percentage \\
\hline Pap smear screening & 44 & $24.4 \%$ \\
\hline HPV vaccine & 02 & $1.1 \%$ \\
\hline
\end{tabular}

About the practice of pap smear, only $24.4 \%$ of the study participant have undergone the screening test and only two participants had taken the HPV vaccine (Table 3 ). In this study, $72.8 \%$ of the participants have told that they 
are interested to undergo pap smear screening in future and $40.6 \%$ are interested to take HPV vaccine in future. (Table 4).

Table 4: Interested to practice in future.

\begin{tabular}{|c|c|c|}
\hline $\begin{array}{l}\text { Interested to practice in } \\
\text { future }\end{array}$ & Frequency & Percentage \\
\hline \multicolumn{3}{|l|}{ Pap smear screening } \\
\hline Yes & 131 & $72.8 \%$ \\
\hline No & 49 & $27.2 \%$ \\
\hline \multicolumn{3}{|l|}{ HPV vaccine } \\
\hline Yes & 107 & $59.4 \%$ \\
\hline No & 73 & $40.6 \%$ \\
\hline
\end{tabular}

\section{DISCUSSION}

In spite of being a major public health problem in developing countries, there aren't any high-level opportunistic screening programs for cervical cancer in India. ${ }^{10-12}$ In the absence of a systematic screening program the expected practice is to opportunistically screen eligible women when they come to health units. Studies have shown it is possible to train nurses to screen for cervical cancer. ${ }^{13}$

In the present study, regarding the knowledge of carcinoma cervix and pap smear, $86.7 \%$ and $74.4 \%$ of the study participants were found to be heard about carcinoma cervix and pap smear screening test, respectively. Whereas only $23.9 \%$ of the participants were aware about the human papilloma virus and only $11.7 \%$ of the study participant were heard about the HPV vaccine. These results were consistent with the study done by Saha et al where $89 \%$ of the respondents had heard of cervical cancer. ${ }^{14}$

Another study by Aswathy et al reported that about $89 \%$ of the respondents in the rural set up were aware of cervical cancer. ${ }^{15}$ Also in their study among 200 subjects, only 1 subject $(0.5 \%)$, was aware of HPV vaccine. $97.9 \%$ of the subjects were unaware of Pap smear.

Aswathy et al showed that $6.9 \%$ of their study group has undergone cervical screening by PAP smear. ${ }^{15}$ The study by Kumar et al showed that $7.2 \%$ of the study participants in Mangalore city had undergone pap smear.16 Sudhir et al conducted a study in Manipal and it showed a very poor result of $2.25 \%$ who have undergone pap testing among their study group. ${ }^{17}$

In this study, $72.8 \%$ showed a willingness to undergo cervical screening in the future and $59.4 \%$ showed willingness to take HPV vaccine, if they are given the facility. Similarly, in the study conducted by Shrestha et al $79 \%$ were interested to undergo pap smear screening. ${ }^{18}$ A study done in Bhopal by Bansal et al showed a willingness of $76.25 \%{ }^{8}$ Thus the willingness among our study group is almost similar to that found in most other studies.

\section{CONCLUSION}

The knowledge of cervical cancer risk factors and sign were very poor but knowledge about the method of prevention was good in the study population. Most of the women had poor attitude and practice related to screening and vaccination for cervical cancer. But their attitude is favourable for screening. Promote free regular health check-up and vaccination for cervical cancer among general population will increase the awareness and decrease the disease burden.

\section{ACKNOWLEDGMENTS}

Authors would like to thank all, who has guided us by extending their knowledge and experience right from the inception to the completion of the work. Also, authors would like to acknowledge the medical superintendent and all the staffs, for their support during the study period. Last but not least authors thankful to this study participants, without whom, this study would not have been possible.

Funding: No funding sources Conflict of interest: None declared

Ethical approval: The study was approved by the Institutional Ethics Committee

\section{REFERENCES}

1. ICMR. National Cancer Registry Programme. Consolidated Report of Population Based Cancer Registries. 2001-2004;2006. Available at: http://www.icmr.nic.in/nrcp/report_pop_2001-2004/I nital\%20 Pages.pdf. Accessed on $22^{\text {th }}$ January 2020.

2. Sankaranarayanan R, Esmy PO, Rajkumar R, Muwonge R, Swaminathan R, Shanthakumari S, et al. Effect of visual screening on cervical cancer incidence and mortality in Tamil Nadu, India: a cluster-randomised trial. Lancet. 2007;370:398-406.

3. Carr KC, Sellors JW. Cervical cancer screening in low resource settings using visual inspection with acetic acid. J Midwifery Womens Health. 2004;49:329-37.

4. Miller AB. Cervical cancer screening programmes: managerial Guidelines. Geneva: World Health Organization; 1992. Available at: https://www.extranet.who.int/iris/restricted/bitstream /10665/39478/1/9241544473.pdf. Accessed on $22^{\text {th }}$ January 2020.

5. Roy B, Tang TS. Cervical cancer screening in Kolkata, India: Beliefs and predictors of cervical cancer screening among women attending a women's health clinic in Kolkata, India. J Cancer Educ. 2008;23:253-9. 
6. Mishra GA, Pimple SA, Shastri SS. An overview of prevention and early detection of cervical cancers. Indian J Med Paediatr Oncol. 2011;32:125-32.

7. Kaarthigeyan K. Cervical cancer in India and HPV vaccination. Indian $\mathrm{J}$ Med Paediatr Oncol. 2012;33:7-12.

8. Bansal AB, Pakhare AP, Kapoor N, Mehrotra R, Kokane AM. Knowledge, attitude, and practices related to cervical cancer among adult women: A hospital-based cross-sectional study. J Nat Sci Biol Med. 2015;6:324-8.

9. Nelson SB, Viswanathan N, Jenifer NA, Priyanka B. A cross-sectional study on cervical cancer and its prevention among women of age group 25- 50 years in a rural area of South Tamil Nadu, India. Int $\mathrm{J}$ Comm Med Public Health. 2018;5:2536-41.

10. Gururaj G. New Delhi: National Commission on Macroeconomics and Health, Ministry of Health and Family Welfare, Government of India; 2005. Injuries in India: A National Perspective. Background Papers: Burden of Disease in India Equitable Development-Healthy Future. 2005:325-347.

11. Hainer R. New guidelines: Pap test should start at age 21 Atlanta: Cable News Network (CNN); 2009. Available at: http:/edition.cnn.com/2009/ HEALTH/11/20/pap.cervical.cancer/index.html. Accessed on $22^{\text {th }}$ January 2020.

12. Sankaranarayanan R, Budukh AM, Rajkumar R. Effective screening programmes for cervical cancer in low- and middle-income developing countries. Bull World Health Organ. 2001;79:954-62.

13. Chirenje ZM, Chipato T, Kasule J, Rusakaniko S. Visual inspection of the cervix as a primary means of cervical cancer screening: results of a pilot study. Cent Afr J Med. 1999;45:30-3.

14. Saha A, Chaudhary AN, Bhowmik P, Chatterjee R. Awareness of cervical cancer among female students of Premier Colleges in Kolkata, India. Asian Pac J Cancer Prev. 2010;11:1085-90.

15. Aswathy S, Quereshi MA, Kurian B, Leelamoni K. Cervical cancer screening: current knowledge and practice among women in a rural population of Kerala, India. Indian J Med Res. 2012;136(2):20510.

16. Kumar H, Tanya S. A study on knowledge and screening for cervical cancer among women in Mangalore city. Ann Med Health Sci Res. 2014;4(5):751.

17. Sudhir, Krishna D. Knowledge and practice about cervical cancer screening among women in a rural population of South India. Sch J App Med Sci. 2014;2(2C):689-93.

18. Shrestha J, Saha R, Tripathi N. Knowledge, attitude and practice regarding cervical cancer screening amongst women visiting tertiary centre in Kathmandu, Nepal. Nepal J Med Sci. 2013;2(2):8590.

Cite this article as: Shantha A, Somu P. Perception about pap smear screening test among females attending a tertiary care center. Int J Reprod Contracept Obstet Gynecol 2020;9:1412-5. 